\title{
Symmetrical Azine Colorimetric and Fluorometric Turn-Off Chemosensor for Formaldehyde Detection
}

(Kolorimetri Simetri Azina dan Fluorometri Mematikan Kemoderia untuk Pengesanan Formaldehid)

\author{
NuRUl HidAyAh, Bambang PURWONO* \& HARnO Dwi PRANOWO
}

\begin{abstract}
Azine derivative 6,6'-((1E,1'E)-hydrazine-1,2-diylidenebis(methanyly-lidene))bis(3,4-dimethoxy-aniline) CHA has been synthesized by condensation of 6-nitroveratraldehyde with malononitrile followed by reduction using $10 \% \mathrm{Pd} / \mathrm{C}$ and hydrazine hydrate. In the presence of formaldehyde, $\mathbf{C H A}$ chemosensor in ethanol showed a yellow-to-red color change observable by the naked eyes and 'turn off' type fluorescence quenching in ethanol. This phenomenon was confirmed by UV-Vis, fluorescence and ${ }^{1} \mathrm{H}$ NMR spectroscopy. The CHA spectra in ethanol was shifted from 412 to 509 nm after addition of formaldehyde. Fluorescence intensity of $\mathbf{C H A}$ gradually decreased with the increase of formaldehyde concentrations. Furthermore, paper strips loaded-CHA were fabricated and served to detect formaldehyde qualitatively. The detection limit of the CHA probe to formaldehyde is $0.2 \mathrm{M}$.
\end{abstract}

Keywords: Azine; chemosensor; colorimetric; fluorometric; formaldehyde; turn off

ABSTRAK

Terbitan azina CHA 6,6'-((1E,1'E)-hidrazina-1,2-diilidenebis(metanili-liden))bis(3,4-dimetoksi-anilin) telah disintesis dengan pemeluwapan 6-nitroveratraldehid dengan malononitril diikuti dengan pengurangan menggunakan 10\% Pd/C dan hidrat hidrazina. Dengan kehadiran formaldehid, kemoderia CHA dalam etanol menunjukkan perubahan warna daripada kuning kepada merah yang boleh diperhatikan oleh mata kasar dan 'mematikan' jenis pemelindapan kependarfluoran dalam etanol. Fenomena ini disahkan oleh UV-vis, kependarfluoran dan spektroskopi ${ }^{1}$ H NMR. Spektrum CHA dalam etanol telah beralih daripada 412 kepada $509 \mathrm{~nm}$ selepas penambahan formaldehid. Keamatan kependarfluoran CHA secara beransur-ansur menurun dengan peningkatan kepekatan formaldehid. Tambahan pula, jalur kertas yang dimuatkanCHA telah direka dan digunakan untuk mengesan formaldehid secara kualitatif. Had pengesanan prob CHA kepada formaldehid adalah $0.2 \mathrm{M}$.

Kata kunci: Azina; fluorometrik; formaldehid; kemoderia; kolorimetri; mematikan

\section{INTRODUCTION}

Formaldehyde is usually found in resins used in manufacturing of wood products, building materials, household products, fertilizers, and pesticides. In addition, formaldehyde is also used as a food preservative illegally, on fish and meat products, wet noodles, and soybean curds. On the other hand, formaldehyde has serious effects on human health such as irritation of the skin, eyes, nose, throat and causes DNA damage (Merk 1998). Moreover, a high concentration of formaldehyde exposure has been reported to cause cancer (Cogliano et al. 2005). For these reasons, it is necessary to develop a simple and costeffective formaldehyde chemosensor.

Research regarding formaldehyde detection methods include using chromatography, spectrophotometry, and enzymatic methods. Li et al. (2007) and Yeh et al. (2013) determined the formaldehyde level in a sample using HPLC and GC-MS. This method has involved longer analysis time, complicated tools, and therefore cannot be used for routine analysis. Korpan et al. (1993) and Nikitina et al. (2007) have designed biosensors to detect formaldehyde enzymatically.
However, it has a low potential because it involves a lot of interference and depended on the environmental conditions ( $\mathrm{pH}$ and temperature), where handling is very complicated. Dar et al. (2013) used Thin Layer Chromatography (TLC) method for formaldehyde determination but this method was unable to measure formaldehyde of samples in high concentration. Spectrophotometric methods in detection of formaldehyde are divided into colorimetric (Mohr 2003; Wei et al. 2019) and fluorometric (Bi et al. 2018; Dong et al. 2016; He et al. 2016; Hidayah et al. 2019; Liu et al. 2015; Ovianto et al. 2017; Roth et al. 2015; Song et al. 2012; Wu et al. 2018; Xu et al. 2016; Zhang et al. 2018; Zhou et al. 2018, 2015). The method has advantages over other methods, namely simpler, easier to handle, cheaper, higher in sensitivity and can be used for routine analysis (Chen et al. 2015; Indang et al. 2009; Li et al. 2007).

Azine derivatives have been reported as colorimetric and fluorometric sensors for cation, anion, and netral compound (Caballero et al. 2005; Kaushik et al. 2018; Li et al. 2011; Martínez et al. 2005; Pei et al. 2018; Peng et al. 2014; Suresh et al. 2010). Many fluorescent sensors 
for the detection of formaldehyde have been developed, but majority of the publications discuss the 'turn on' type probes (He et al. 2016; Liu et al. 2015; Song et al. 2012; Xu et al. 2016; Zhang et al. 2018; Zhou et al. 2015). In this work, we report a dual-mode chemosensor for formaldehyde detection from symmetrical azine derivative CHA. The probe can be synthesized from condensation of 6-nitroveratraldehyde and malononitrile followed by one-step reduction of CHA-1 to produce the target probe of CHA (Figure 1). The chemosensor CHA can be used for formaldehyde detection through colorimetric (produces a distinct color change from yellow to red) and 'turn off' fluorescent quenching mechanism in ethanol.

\section{MATERIALS AND EQUIPMENTS}

Materials used for synthesis were 6-nitroveratraldehyde $\left(\mathrm{C}_{9} \mathrm{H}_{9} \mathrm{NO}_{5}\right)$, malononitrile $\left(\mathrm{CH}_{2}(\mathrm{CN})_{2}\right), 10 \% \mathrm{Pd} / \mathrm{C}$, hydrazine hydrate $80 \%$, and distilled water. Solvent used for UV-Vis and fluorescence spectra measurement was absolute ethanol. These chemicals were pro analytic reagents from Merck, except for distilled water.

Equipment used for the synthesis was a set reflux, hot plate magnetic stirrer, and laboratory glassware. Instruments employed for characterization of synthesis product were melting point (Electrothermal 9100), FT-IR spectrophotometer (Shimadzu Prestige 21), Gas Chromatography-Mass Spectrometry (Shimadzu QP2010S), and NMR spectrometer (JEOL JNM-ECZ500R). For UV-Visible and fluorescence measurements, spectrophotometer UV-Vis (Shimadzu UV-1800) and spectrofluorophotometer (Shimadzu RF-6000) were used.

\section{METHODS}

\section{SYNTHESIS OF 2-(4,5-DIMETHOXY-2-NITROBENZYLIDINE) MALONONITRILE (CHA-1)}

The synthesis of 2-(4,5-dimethoxy-2-nitrobenzylidine) malononitrile CHA-1 was accomplished using a modified method from Li et al. (2015). A mixture of malononitrile ( $2 \mathrm{mmol})$ and 6-nitroveratraldehyde $(2 \mathrm{mmol})$ in water was refluxed for $24 \mathrm{~h}$ and the progress of the reaction was monitored by TLC. After the completion of the reaction, the solid product was filtered, washed with water and stored in desiccator. The 2-(4,5-dimethoxy-2-nitrobenzylidine) malononitrile was obtained by recrystallization from ethanol and water as greenish-needle-shaped solid (0.38 $\mathrm{g}, 60.81 \%$, mp $\left.145-146^{\circ} \mathrm{C}\right)$. FT-IR $(\mathrm{KBr}) \cup\left(\mathrm{cm}^{-1}\right): 1064$ and $1180(\mathrm{C}-\mathrm{O}-\mathrm{C}), 2237(\mathrm{C} \equiv \mathrm{N}), 1604(\mathrm{C}=\mathrm{C}), 1519$ and $1327\left(\mathrm{NO}_{2}\right) ;{ }^{1} \mathrm{H}$ NMR $\left(500 \mathrm{MHz}, \mathrm{CDCl}_{3}\right) \delta_{\mathrm{H}}(\mathrm{ppm}): 4.05$ (s, 6H), $7.26(\mathrm{~s}, 1 \mathrm{H}), 7.80(\mathrm{~s}, 1 \mathrm{H}), 8.46(\mathrm{~s}, 1 \mathrm{H})$; MS (EI) for $\mathrm{C}_{12} \mathrm{H}_{9} \mathrm{~N}_{3} \mathrm{O}_{4} \mathrm{~m} / \mathrm{z}: 259.0\left(\mathrm{M}^{+}\right)$.

\section{SYNTHESIS OF 6,6'-((1E,1'E)-HYDRAZINE-1,2- DIYLIDENEBIS(METHANYLYLIDENE))BIS(3,4- DIMETHOXYANILINE) (CHA)}

The synthesis of 6,6'-((1E,1'E)-hydrazine1,2 -diylidenebis (methanylylidene)) bis $(3,4$ dimethoxyaniline) (CHA) was accomplished using a modified Tamami and Yeganeh (2001) method. To a solution of CHA-1 in ethanol $(0.5 \mathrm{mmol})$ was added $10 \%$ $\mathrm{Pd} / \mathrm{C}(0.04 \mathrm{~g})$. The mixture was stirred and warmed to about $50^{\circ} \mathrm{C}$, whereupon $80 \%$ hydrazine hydrate $0.4 \mathrm{~mL}$ in $1 \mathrm{~mL}$ of ethanol was added slowly using dropping funnel. After the addition was completed, the mixture was refluxed for $2 \mathrm{~h}$ at $78^{\circ} \mathrm{C}$ (the reaction was monitored by TLC) and filtered while it was still hot. The crude product as solid was obtained from evaporation of the solvent. The solid was recrystallized from water and ethanol as yellow solid $\left(0.11 \mathrm{~g}, 44 \%, \mathrm{mp} 260-261^{\circ} \mathrm{C}\right)$. FT-IR (KBr) v $\left(\mathrm{cm}^{-1}\right)$ : 1141 and $1188(\mathrm{C}-\mathrm{O}-\mathrm{C}), 1242$ and $1273(\mathrm{C}-\mathrm{N})$, $1604(\mathrm{C}=\mathrm{N}), 3371$ and $3441\left(\mathrm{NH}_{2}\right) ;{ }^{1} \mathrm{H}$ NMR $(500 \mathrm{MHz}$, $\left.\mathrm{CDCl}_{3}\right) \delta_{\mathrm{H}}(\mathrm{ppm}): 3.83$ and $3.88(\mathrm{~s}, 6 \mathrm{H}), 6.07(\mathrm{~s}, 2 \mathrm{H}), 6.24$ $(\mathrm{s}, 1 \mathrm{H}), 6.73(\mathrm{~s}, 1 \mathrm{H}), 8.62(\mathrm{~s}, 1 \mathrm{H}) ;{ }^{13} \mathrm{C}$ NMR $(125 \mathrm{MHz}$, $\left.\mathrm{CDCl}_{3}\right) \delta_{\mathrm{C}}(\mathrm{ppm}):$ 55.98, 56.82, 99.32, 108.09, 115.99, 141.08, 144.30, 152.69, 162.49; MS (EI) for $\mathrm{C}_{18} \mathrm{H}_{22} \mathrm{~N}_{4} \mathrm{O}_{4}$ $\mathrm{m} / \mathrm{z}: 358\left(\mathrm{M}^{+}\right)$.

\section{GENERAL PROCEDURE FOR UV-VISIBLE AND FLUORESCENCE SPECTRA MEASUREMENT}

Generally, the procedure to generate the UV-Vis and fluorescence spectra were the same with the previous work by Hidayah et al. (2019). The solutions of chemosensor CHA was prepared by dissolving CHA solid in ethanol until it dissolves completely. The $37 \%$ of formaldehyde in water (saturated solution=13.3 M) were used to make the final concentration of $1 \times 10^{-2} \mathrm{M}$. Formaldehyde concentration of $0,1,3,5,7,9,10,20,40,60,80,100,120,140,160$, 180 , and $200 \times 10^{-2} \mathrm{M}$ was added into CHA chemosensor ethanol solution and then the UV-visible and flourescence spectra were recorded.<smiles>COc1cc(C=NN=Cc2cc(OC)c(OC)cc2N)c(N)cc1C=NN=CC(C)(C)N</smiles> 


\section{APPLICATION OF CHA AS PAPER STRIP}

The paper strip for qualitative testing was prepared by immersing the filter papers (Whatman no. 42) in the CHA ethanol solution $\left(1 \times 10^{-3} \mathrm{M}\right)$ for $15 \mathrm{~min}$ followed by drying in the oven. Detection formaldehyde using the filter paper was carried out by two drops different concentrations of formaldehyde solution, i.e., 1.4, 1.6, 1.8,2 M, and saturated solution (13.3 M) on the surface of the papers, respectively. Distilled water was also dropped to the paper strip as a negative control. Detection of formaldehyde in a vapor phase was performed by putting paper strip above the formaldehyde solution (1 M) in a vial and water was used as the negative control without dipping it in the solution. To confirm the detection ability of the paper strip, meatballs were tested by paper strip loaded with CHA. First, the meatballs were immersed in $1 \mathrm{M}$ formaldehyde solution for overnight. The meatballs were then weighed $(1 \mathrm{~g})$, crushed with a mortar, and distilled water $(10 \mathrm{~mL})$ was added followed by filtration process. At last, the filtrate obtained was dropped onto the paper strip loaded with CHA compound.

\section{RESULTS AND DISCUSSION}

\section{UV-VIS ABSORPTION STUDY OF CHA}

The CHA chemosensor was synthesized by condensation of 6-nitroveratraldehyde with malononitrile to give CHA-1 which upon reduction gave an symmetrical azine containing the amine group. The structue of prepared compounds have been fully characterized by FT-IR, ${ }^{1} \mathrm{H}$ NMR, ${ }^{13} \mathrm{C}$ NMR, and EI-MS analysis and agreed with the literature. The response of CHA as a sensor was examined by adding $10 \mu \mathrm{L}$ of formaldehyde into a solution of $\mathbf{C H A}$ in ethanol. The color of the CHA solution changed from yellow to red immediately after addition of formaldehyde. This color change was confirmed using UV-Vis spectra as presented in Figure 2. The UV-Vis spectra showed that CHA ethanol solution has maximum wavelength of 412 $\mathrm{nm}$ which shifted to maximum wavelength of $509 \mathrm{~nm}$ after addition of formaldehyde. The color change of CHA solution after the addition of formaldehyde is the result of chemodosimeter type between chemosensor CHA and formaldehyde as Figure 3.

The $-\mathrm{NH}_{2}$ of $\mathbf{C H A}$ probe as a binding group reacts with formaldehyde to form an imine. The formation of imine $(-\mathrm{C}=\mathrm{N}-)$ induced extended delocalization of the electrons

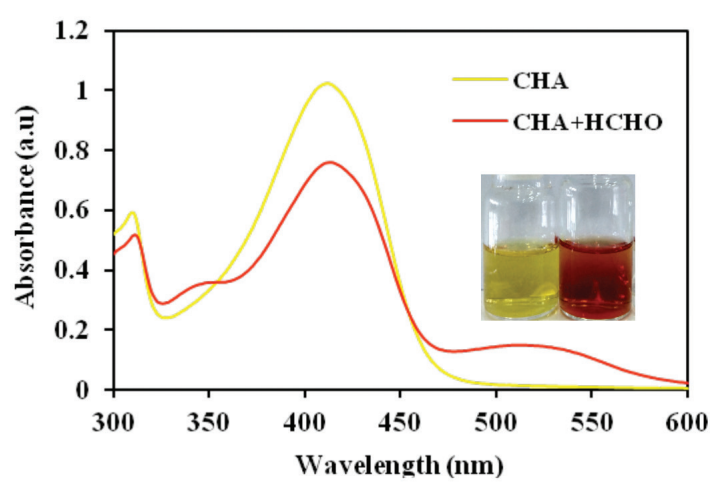

FIGURE 2. The UV-Vis spectra of CHA $\left(2.5 \times 10^{-5} \mathrm{M}\right.$ in ethanol $)$ before and after addition of formaldehyde (200 equiv.). Inset: Photographs of compound CHA $\left(1 \times 10^{-4} \mathrm{M}\right.$ in ethanol) before (left) and after addition of formaldehyde (right)

and the yellow color changed to red color (bathochromic shift). As shown in Figure 4, the spectra showed the peak of amine proton of CHA before addition formaldehyde solution that appeared at $\delta 6.8 \mathrm{ppm}$. After addition of formaldehyde, two new peaks were observed at $\delta 5.8$ and $6.1 \mathrm{ppm}$, which indicate as the imine proton, the result of the reaction of the amine group in CHA with formaldehyde. Two methylene proton in imine structure have a different chemical environment, and the new peaks which appeared with high intensity in the range of $\delta 3-5$ ppm were proton peaks of formaldehyde (Lewicki et al. 2015; Wu et al. 2018). Increase of formaldehyde addition from 80 to 200 equivalent reduced peak at $\delta 6.8 \mathrm{ppm}$ and increased peak at $\delta 5.8$ and $6.1 \mathrm{ppm}$.

The stability of CHA-Formaldehyde interaction was also studied by time dependence of UV-Vis spectra. The result indicated that after $3 \mathrm{~h}$ addition of formadehyde the wavelength of $509 \mathrm{~nm}$ and $412 \mathrm{~nm}$ has decreased and the wavelength of $363 \mathrm{~nm}$ has appeared. The red color solution of CHA-formaldehyde has also changed to colorless (Figure $5)$.

As red color changed to colorless and wavelength shifted to hypsochromic, the imine group was hydrolyzed to aldehyde group. This result was also confirmed using NMR proton titration. As seen in Figure 4, the spectra of CHA-formaldehyde after $3 \mathrm{~h}$ addition appeared a new peak at $9.6 \mathrm{ppm}$. This peak indicated as a proton from aldehyde which is the result of hydrolysis of imine.

In order to determine the colorimetric response of CHA to formaldehyde, titration measurements with various<smiles>C=Nc1cc(OC)c(OC)cc1C=NN=Cc1cc(OC)c(OC)cc1N=Cc1cc(OC)c(OC)cc1N=C</smiles>

CHA

FIGURE 3. Reaction of CHA with formaldehyde in etanol 


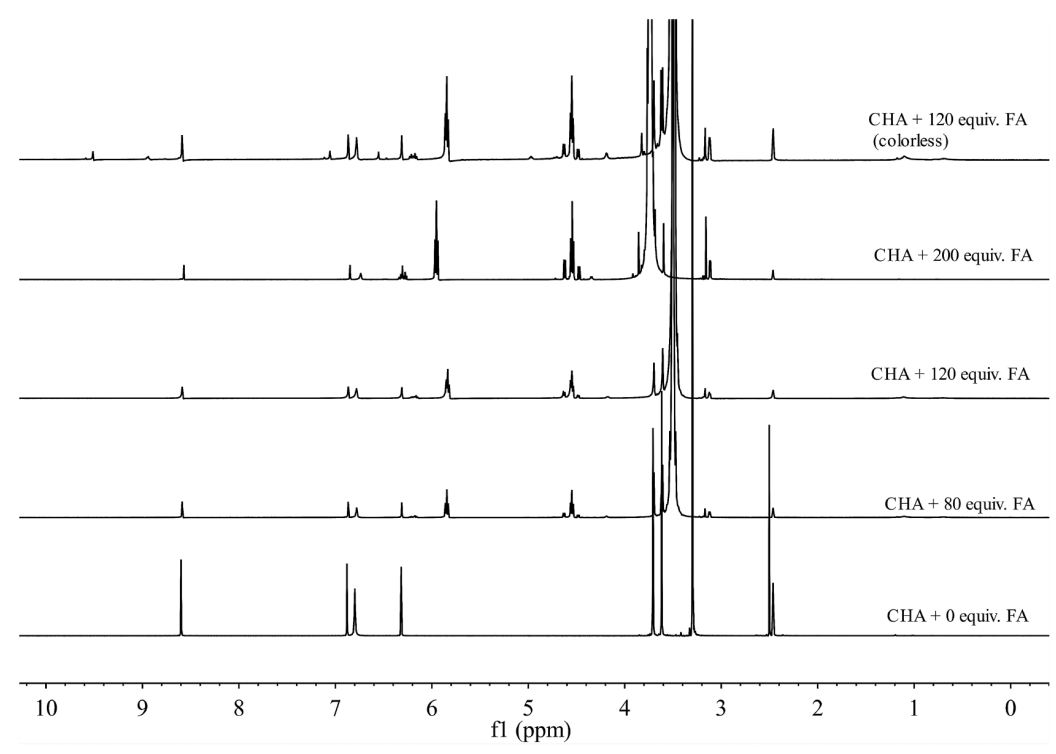

FIGURE 4. ${ }^{1} \mathrm{H}$ NMR titration spectra changes of CHA upon addition of formaldehyde in DMSO- $\mathrm{d}_{6}$

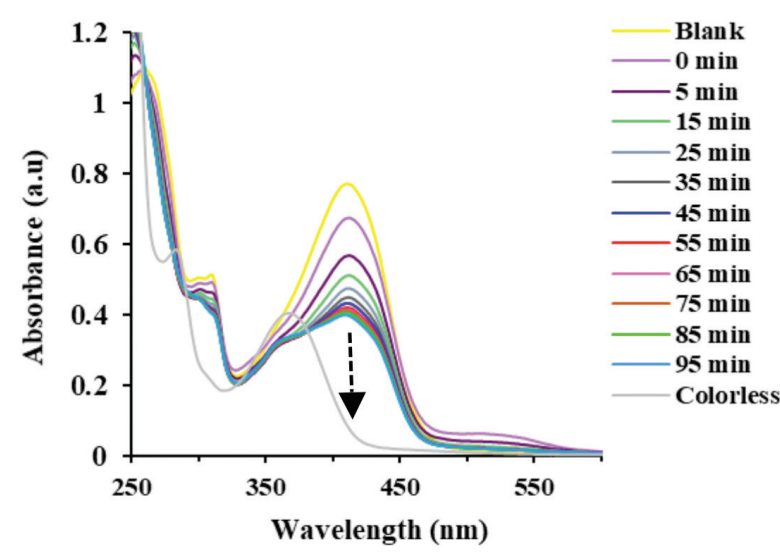

FIGURE 5. Changes in the UV-Vis spectra of CHA $\left(2.5 \times 10^{-5}\right.$ $\mathrm{M})$ in ethanol as a time course after addition of formaldehyde solution (200 equiv.) and colorless for $3 \mathrm{~h}$

concentrations of formaldehyde (0-200 equiv.) were carried out. As shown in Figure 6, increasing the formaldehyde concentration leads to the enhancing of absorption at 509 $\mathrm{nm}$, and declining at the wavelength of $412 \mathrm{~nm}$. Then, the limit of detection was calculated with the UV-Vis data, using formula as IUPAC recommendations, LOD: $3 \sigma / \mathrm{m}$, where $\sigma$ represents the standard deviation of blank, $m$ is slope of the equation that obtained from the ratio of absorption at $509 \mathrm{~nm}$ and $412 \mathrm{~nm}$ (plot $\mathrm{A}_{509} / \mathrm{A}_{412}$ ) versus concentration of formaldehyde ( $\mathrm{HCHO}$ ) (Borase et al. 2016), LOD of CHA was $0.74 \mathrm{M}$.

\section{FLUORESCENCE RESPONSE OF CHA TOWARD FORMALDEHYDE}

The fluorescent properties of CHA $\left(2.5 \times 10^{-4} \mathrm{M}\right.$ in ethanol $)$ in the absence and presence of formaldehyde were determined. The CHA solution showed a strong fluorescence property, but after addition of formaldehyde, CHA was almost non-fluorescent. Chemosensor of CHA presented a strong absorption band at $\lambda=440 \mathrm{~nm}$ and was chosen as the excitation wavelength for fluorescence measurement. At $\lambda_{\text {ex }}=440 \mathrm{~nm}$, the CHA solution demonstrated a maximum emission spectrum at $506 \mathrm{~nm}$. Formaldehyde solutions at different concentrations (0-200 equiv.) were added
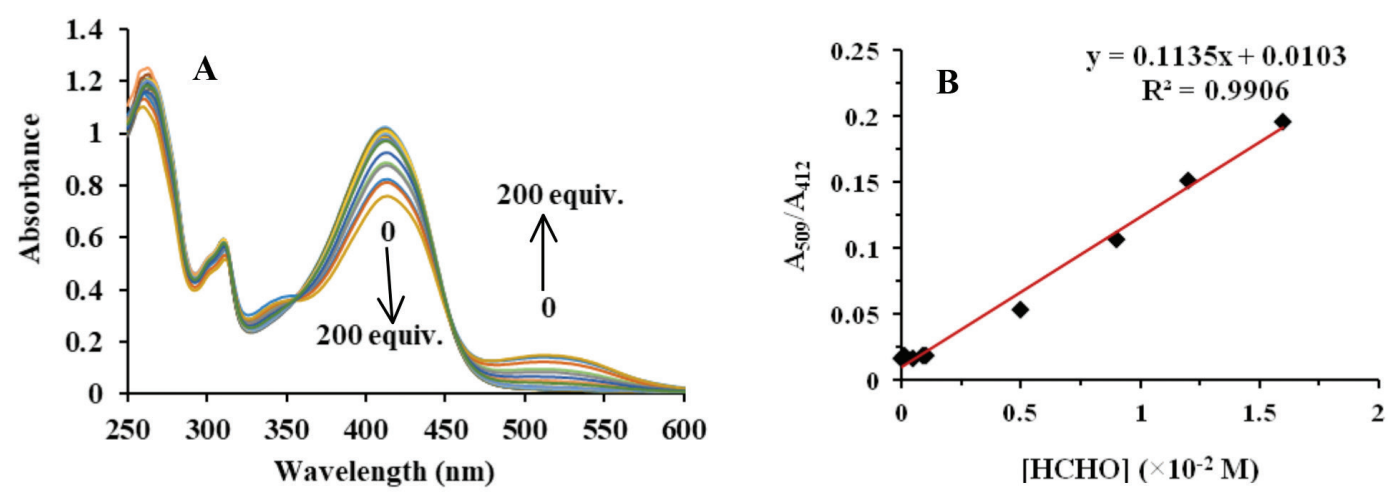

FIGURE 6. The UV-Vis spectra of CHA $\left(2.5 \times 10^{-5} \mathrm{M}\right)$ in ethanol with increasing the concentration of formaldehyde (0-200 equiv.) (A). Plot of $\mathrm{A}_{509} / \mathrm{A}_{412}$ against concentrations of $\mathrm{HCHO}$ (B) 
into the CHA chemosensor in ethanol solution $\left(2.5 \times 10^{-4}\right.$ M) and the results were shown in Figure 7. As shown in Figure 7, when the addition of formaldehyde concentration increased, the fluorescence intensity of the compound CHA was decreasing. The result suggested that formation of imine quenched the fluorescence intensity, implying that CHA could be used as a 'turn-off' chemosensor for formaldehyde.

The limit of detection was calculated from the plot of $\mathrm{F}_{0} / \mathrm{F}$ versus concentration of formaldehyde ( $\mathrm{HCHO}$ ), where $\mathrm{F}_{0}$ and $\mathrm{F}$ is the fluorescence intensity of CHA in the absence of formaldehyde and at a certain concentration of formaldehyde, respectively. The Stern-Volmer plot in Figure 7 presented a linear relationship with $\mathrm{R}=0.9658$ and the LOD was estimated to be $0.20 \mathrm{M}$.

To study for possible interference with other types of aldehydes in an application of CHA as the formaldehyde chemosensor, we measured the fluorescence intensity measurement of CHA after the addition of different aldehydes. As seen in Figure 8, except for glutaraldehyde, there was no interference effect of other aldehydes in the detection of formaldehyde.

\section{APPLICATION OF CHA AS PAPER STRIP}

A simple paper test was developed to demonstrate the practical application of CHA chemosensor for detecting of formaldehyde visually. As shown in Figure 9, the paper dropped with a saturated water solution of formaldehyde (1 drop) changed its color from yellow to reddish. Whereas, the paper strip with water as negative control had no noticeable color change that could be observed by the naked eye. Application of CHA for detection formaldehyde as paper strip was also prepared by dropping formaldehyde at the various concentrations into paper loaded CHA and observed it under $365 \mathrm{~nm}$ portable UV lamp. The results (Figure 8) showed that the fluorescence was completely quenched with gradually increasing concentration of
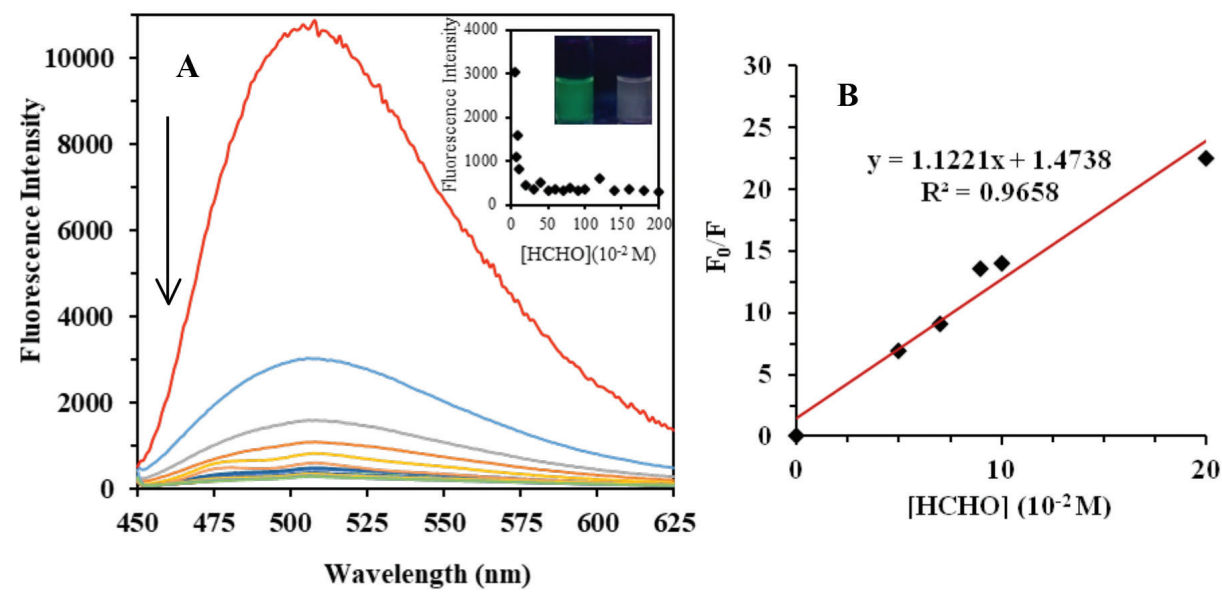

FIGURE 7. Emission spectra of CHA $\left(2.5 \times 10^{-4} \mathrm{M}\right.$ in ethanol) upon addition of formaldehyde in aqueous solution (0-200 equiv.) with excitation at $440 \mathrm{~nm}$. Inset: fluorescence intensity as a function of formaldehyde concentration; photographs of compound CHA $\left(2.5 \times 10^{-4} \mathrm{M}\right.$ in ethanol) before (left) and after (right) addition of formaldehyde under $365 \mathrm{~nm}$ portable UV lamp (A). Stern-Volmer plot of CHA against concentrations of HCHO (B)

SELECTIVITY STUDY

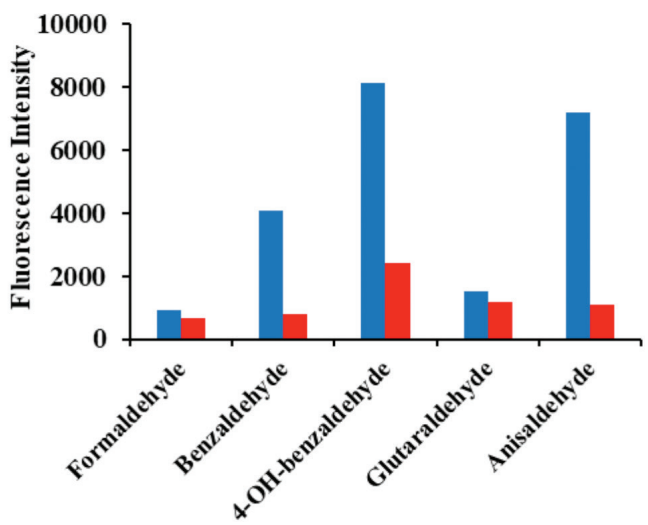

FIGURE 8. Fluorescence intensity of CHA $\left(1 \times 10^{-4} \mathrm{M}\right.$ in ethanol) at $506 \mathrm{~nm}$ after addition of different aldehyde compounds (200 equiv.) (blue bars); the mixture of CHA and formaldehyde after addition of other aldehyde compounds (red bars) 


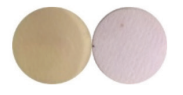

B

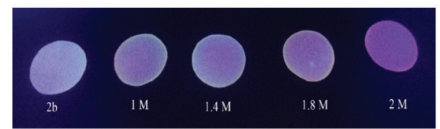

C

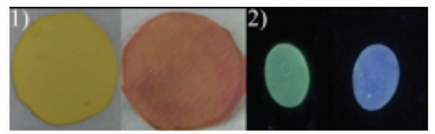

FIGURE 9. Photographs of chemosensor CHA $\left(1 \times 10^{-3} \mathrm{M}\right.$ in ethanol) as paper strip after addition water (left) and formaldehyde (right) in daylight (A), after addition of formaldehyde at various concentrations under $365 \mathrm{~nm}$ portable UV lamp (B), and application of meatball test; 1) before and after addition of metball filtrate in colorimetric; 2 ) before and after addition of metball filtrate in fluorometric (C)

formaldehyde. Furthermore, the test paper which had been loaded with CHA and exposed to formaldehyde in gases phase turned to reddish, while those who were exposed to water as a control did not change.

Then, to demonstrate the applicability of paper strip for formaldehyde detection directly, meatball as a food sample was tested. As shown in Figure 9, paper strip added meatball filtrate containing formaldehyde changed from yellow to red quickly and the appearance was quenched. Based on these results, it can be concluded that the paper strip of CHA can be used to detect formaldehyde in the form of solutions and gases phases qualitatively.

\section{CONCLUSION}

In conclusion, a colorimetric and fluorometric chemosensor CHA for formaldehyde detection has been developed with high selectivity and sensitivity. Moreover, the sensor exhibits a obvious color change from yellow to red after addition of formaldehyde quickly. In this work, compound CHA was successfully applied as paper strip for formaldehyde detection.

\section{ACKNOWLEDGEMENTS}

We are grateful to the Ministry of Research, Technology, and Higher Education of the Republic of Indonesia (RISTEK DIKTI) for financial support this study through Master Program of Education Leading to Doctoral Degree for Excellent Graduates (PMDSU) (1511/E4.4/2015).

\section{REFERENCES}

Bi, A., Gao, T., Cao, X., Dong, J., Liu, M., Ding, N., Liao, W. \& Zeng, W. 2018. A novel naphthalimide-based probe for ultrafast, highly selective and sensitive detection of formaldehyde. Sensors and Actuators, B: Chemical 255: 3292-3297.

Borase, P.N., Pranila, B.T. \& Ganapati, S.S. 2016. Dihydroquinazolinone based 'turn-off' fluorescence sensor for detection of $\mathrm{Cu}^{+}$Ions. Dyes and Pigments 134: 276-284.

Caballero, A., Rosario, M., Vega, L., Imma, R., José, V., Klaus, W., Alberto, T., Pedro, M. \& Jaume, V. 2005. Highly selective chromogenic and redox or fluorescent sensors of $\mathrm{Hg} 2+$ in aqueous environment based on 1,4-disubstituted azines. Journal of the American Chemical Society 127(45): 15666-15667.
Chen, Y., Wei, S., Yonghai, H., Xinhua, S., Linxian, X., Lei, F. \& Zhengfeng, X. 2015. A new highly selective fluorescent turn-on chemosensor for cyanide anion. Talanta 137: 38-42.

Cogliano, V.J., Yann, G., Robert, A.B., Kurt, S., Marie, B.S. \& Fatiha, E.G. 2005. Meeting report: Summary of IARC monographs on formaldehyde, 2-butoxyethanol, and 1-tertbutoxy-2-propanol. Environmental Health Perspectives 88(9): 1205-1208.

Dar, A., Umer, S. \& Jamil, A. 2013. A simple spot test quantification method to determine formaldehyde in aqueous samples. Journal of Saudi Chemical Society 20: S352-S356.

Dong, B., Xuezhen, S., Yonghe, T. \& Weiying, L. 2016. A rapid and facile fluorimetric method for detecting formaldehyde. Sensors and Actuators, B: Chemical 222: 325-330.

He, L., Xueling, Y., Mingguang, R., Xiuqi, K., Yong, L. \& Weiying, L. 2016. An ultra-fast illuminating fluorescent probe for monitoring formaldehyde in living cells, shiitake mushrooms, and indoors. Chemical Communication 52(61): 9582-9585.

Hidayah, Purwono, N.B., Nurohmah, B.A. \& Pranowo, H.D. 2019. Synthesis of pyridine derivative-based chemosensor for formaldehyde detection. Indonesian Journal of Chemistry 19(4): 1074-1080.

Indang, M.N., Abdulamir, A.S., Bakar, B.A., Salleh, A.B., Lee, Y.H. \& Azah, N. 2009. A review: Methods of determination of health-endangering formaldehyde in diet. Research Journal of Pharmacology 3(2): 31-47.

Kaushik, R.,Amrita, G.,Ajeet, S. \& Jose,A.D. 2018. Colorimetric sensor for the detection of $\mathrm{H} 2 \mathrm{~S}$ and its application in molecular half-subtractor. Analytica Chimica Acta 1040: 177-186.

Korpan, Y.I., Gonchar, M.V., Starodub, N.F., Shulga, A.A., Sibirny, A.A. \& Elskaya, A.V. 1993. A cell biosensor specific for formaldehyde based on $\mathrm{pH}$-sensitive transistors coupled to methylotrophic yeast cells with genetically adjusted metabolism. Analytical Biochemistry 215(2): 216-222.

Lewicki, J.P., Christina, A.F. \& Marcus, A.W. 2015. On the synthesis and structure of resorcinol-formaldehyde polymeric networks-precursors to 3D-carbon macroassemblies. Polymer 69(1): 45-51.

Li, J., Junli, Z. \& Lifang, Y. 2007. Determination of formaldehyde in squid by high- performance liquid chromatography. Asia Pacific Journal of Clinical Nutrition 16: 127-130.

Li, Q., Yiai, C., Hong, Y., Qi, L., Yuan, R.Z., Hui, L., You, M.Z. \& Tai, B.W. 2015. A colorimetric and fluorescent cyanide chemosensor based on dicyanovinyl derivatives: Utilization of the mechanism of intramolecular charge transfer blocking. Spectrochimica Acta - Part A: Molecular and Biomolecular Spectroscopy 136: 1047-1051. 
Li, Q., Yong, G., Jian, X. \& Shijun, S. 2011. Salicylaldehyde based colorimetric and 'turn on' fluorescent sensors for fluoride anion sensing employing hydrogen bonding. Sensors and Actuators, B: Chemical 158(1): 427-431.

Li, Q., Piyanete, S. \& Shoji, M. 2007. Development of novel reagent for Hantzsch reaction for the determination of formaldehyde by spectrophotometry and fluorometry. Analytical Sciences: The International Journal of the Japan Society for Analytical Chemistry 23(4): 413-417.

Liu, C., Caixia, S., Haixia, L., Weiwei, D., Zhanxian, L., Liuhe, W. \& Mingming, Y. 2015. Nanomolar fluorescent quantitative detection of formaldehyde with a 8-hydroxyquinoline derivative in aqueous solution and electrospun nanofibers. Sensors and Actuators, B: Chemical 219: 185-191.

Martínez, R.,Arturo, E.,Alberto, T. \& Pedro, M. 2005. New Hg2+ and $\mathrm{Cu} 2+$ selective chromo- and fluoroionophore based on a bichromophoric azine. Organic Letters 7(26): 5869-5872.

Merk, O. 1998. Significance of formaldehyde-induced DNAprotein crosslinks for mutagenesis. Environmental and Molecular Mutagenesis 32: 260-268.

Mohr, G.J. 2003. New chromoreactands for the detection of aldehydes, amines and alcohols. Sensors and Actuators, B: Chemical 90: 31-36.

Nikitina, O., Sergey, S., Galina, G., Olha, D., Mykhaylo, G., Lo, G., Elisabeth, C. \& Mihaela, N. 2007. Bi-enzyme biosensor based on NAD+- and glutathione-dependent recombinant formaldehyde dehydrogenase and diaphorase for formaldehyde assay. Sensors and Actuators, B: Chemical 125(1): 1-9.

Ovianto, D., Sugiharta, I.B.A.R. \& Purwono, B. 2017. Synthesis of 4-Phenyl-2,6-Bis (4-aminophenyl) pyridine compound and study of their fluorescence behaviour for formaldehyde sensing. International Journal of ChemTech Research 10(9): 918-923.

Pei, P.X., Hu, J.H., Long, C. \& Ni, P. 2018. A novel colorimetric and 'turn-on' fluorimetric chemosensor for selective recognition of $\mathrm{CN}$ - ions based on asymmetric azine derivatives in aqueous media. Spectrochimica Acta-Part A: Molecular and Biomolecular Spectroscopy 198: 182-187.

Peng, L., Zhou, Z., Wei, R., Li, K., Song, P. \& Tong, A. 2014. A fluorescent probe for thiols based on aggregation-induced emission and its application in live-cell imaging. Dyes and Pigments 108: 24-31.

Roth, A.,Li, H. \& Anorma, C. 2015.A reaction-based fluorescent probe for imaging of formaldehyde in living cells. Journal of the American Chemical Society 1: 10-13.

Song, H., Rajendiran, S., Kim, N., Jeong, S.K., Koo, E., Park, G., Thangadurai, T.D. \& Yoon, S. 2012. A tailor designed fluorescent 'turn-on' sensor of formaldehyde based on the BODIPY motif. Tetrahedron Letters 53(37): 4913-4916.
Suresh, M., Mandal, A.K., Saha, S., Suresh, E., Mandoli, A., Liddo, R.D., Parnigotto, P.P. \& Das, A. 2010. Azine-based receptor for recognition of $\mathrm{Hg} 2+$ Ion: Crystallographic evidence and imaging application in live cells. Organic Letters 12(23): 5406-5409.

Tamami, B. \& Yeganeh, H. 2001. Synthesis and characterization of novel aromatic polyamides derived from 4-Aryl-2,6-Bis(4Aminophenyl) pyridines. Polymer 42(2): 415-420.

Wei, K., Ma, L., Ma, G., Ji, C. \& Yin, M. 2019. A twostep responsive colorimetric probe for fast detection of formaldehyde in weakly acidic environment. Dyes and Pigments 165: 294-300.

Wu, Y., Zheng, Z., Wen, J., Li, H., Sun, S. \& Xu, Y. 2018 Imaging of formaldehyde in live cells and plants utilizing small molecular probes with large stokes shifts. Sensors and Actuators, B: Chemical 260: 937-944.

Xu, J., Zhang, Y., Zeng, L., Liu, J., Kinsella, J.M. \& Sheng, R. 2016. Talanta a simple naphthalene-based Fl uorescent probe for high selective detection of formaldehyde in toffees and HeLa cells via aza-cope reaction. Talanta 160: 645-652.

Yeh, T.S., Lin, T.C., Chen, C.C. \& Wen, H.M. 2013. Analysis of free and bound formaldehyde in squid and squid products by gas chromatography-mass spectrometry. Journal of Food and Drug Analysis 21(2): 190-197.

Zhang, D., Liu, D., Li, M., Yang, Y., Wang, Y., Yin, H., Liu, J., Jia, B. \& Wu, X. 2018. A simple pyrene-based fluorescent probe for highly selective detection of formaldehyde and its application in live-cell imaging. Analytica Chimica Acta 1033: $180-184$

Zhou, W., Dong, H., Yan, H., Shi, C. \& Yu, M. 2015. Chemical HCHO-reactive molecule with dual-emission-enhancement property for quantitatively detecting $\mathrm{HCHO}$ in near $100 \%$ water solution. Sensors \& Actuators: B. Chemical 209: 664-669.

Zhou, Y., Yan, J., Zhang, N., Li, D., Xiao, S. \& Zheng, K. 2018. A ratiometric fluorescent probe for formaldehyde in aqueous solution, serum and air using aza-cope reaction. Sensors and Actuators, B: Chemical 258: 156-162.

Department of Chemistry

Universitas Gadjah Mada

Bulaksumur, 55281 Yogyakarta

Indonesia

*Corresponding author; email: purwono.bambang@ugm.ac.id

Received: 21 May 2019

Accepted: 1 August 2019 